\title{
PROFILE OF SEVERAL AUTOANTIBODIES, COMPLEMENT AND VITAMIN D LEVELS IN BRAZILIAN PATIENTS WITH CHIKUNGUNYA INFECTION
}

\author{
J.F. Carvalho ${ }^{a}$, L.R. Cordeiro ${ }^{a}$, F.F. Silva ${ }^{b}$, L. Mota ${ }^{c}$, C. Rodrigues ${ }^{d}$, C.F. Andrade A,f $^{\text {, }}$ \\ C. Caldas ${ }^{g}$ \\ ${ }^{a}$ Federal University of Bahia, Salvador, Brazil \\ ${ }^{b}$ University of São Paulo, São Paulo, Brazil \\ ${ }^{c}$ University of Brasilia, Brasilia, Brazil \\ ${ }^{d}$ University of Fortaleza, Fortaleza, Brazil \\ ${ }^{e}$ National School of Public Health Sérgio Arouca, Rio de Janeiro, Brazil \\ ${ }^{f}$ Vassouras University, Rio de Janeiro, Brazil \\ ${ }^{g}$ Federal University of Pará, Belém, Brazil
}

\begin{abstract}
Introduction. Chikungunya virus infection (CKV) may lead to chronic arthritis in up to $40 \%$ of the patients. There are previous data regarding positive autoantibodies in CKV. Objective is to systematically evaluate the prevalence of autoantibodies in CKV patients. Methods. All study participants had clinical manifestations being CKV positive at least serologally or by RT-PCR data. The following autoantibodies were assessed: antinuclear antibodies (ANA), anti-dsDNA, anti-Sm, anti-Ro/SS-A, anti-La/SS-B, anti-U1RNP, IgG and IgM anticardiolipin, anticyclic citrullinated peptide (anti$\mathrm{CCP}$ ), rheumatoid factor (RF), antiribosomal P protein, lupus anticoagulant, anti-Jo-1 and anti-Scl-70. CH100, C3 and $\mathrm{C} 4$ complement components, serum levels of immunoglobulins, C-reactive protein, erythrocyte sedimentation rate, alpha1-acid glycoprotein, antithyroglobulin, antithyroperoxidase, TRAb, 25 hydroxyvitamin D (25OHD), dengue and zika $\mathrm{IgG}$ and IgM antibodies were also measured. Results. $30 \mathrm{CKV}$ patients were included. Mean age was $59.1 \pm 15.7$ years, $85 \%$ females and 77\% Caucasian subjects. Disease duration comprised $4.9 \pm 4.0$ months. Oligoarthritis was observed in $93 \%$ cases. Mean C-reactive protein levels were $10.1 \pm 6.8 \mathrm{ng} / \mathrm{dL}$, erythrocyte sedimentation rate $-34.2 \pm 19.9 \mathrm{~mm} / 1^{\text {st }}$ hour and alpha1-acid glycoprotein $115.5 \pm 52.6 \mathrm{mg} / \mathrm{dL}$. Intramuscular betamethasone depot single dose injection was administered in 54\%, prednisone - in 15\% and methotrexate - in 23\% cases. Importantly, 1/30 (3.3\%) cases was positive for ANA, $4 / 30(13.3 \%)$ - for RF and none was positive for anti-CCP or any other autoantibodies. Complement and immunoglobulin levels were all within the normal range. Low levels of 25OHD were observed in $88 \%$ cases.
\end{abstract}

Key words: Chikungunya, autoantibodies, autoimmunity, arboviruses, rheumatoid arthritis.

\section{Адрес для переписки:}

Джозелио Фрейре Карвальо

Бразилия, г. Салвадор, Федеральный университет Баии.

E-mail: jotafc@gmail.com

\section{Для цитирования:}

Карвальо Дж.Ф., Кордейро Л.Р., Силва Ф.Ф., Мота Л., Родригес К., Андраде К.Ф., Кальдас С. Профиль уровней некоторых аутоантител, комплемента и витамина D у больных с инфекцией Чикунгунья в Бразилии // Инфекция и иммунитет. 2021. Т. 11, № 5. С. 979-983. doi: 10.15789/2220-7619-POS-1614

\section{Contacts:}

Jozélio Freire Carvalho

Brazil, Salvador, Federal University of Bahia.

E-mail: jotafc@gmail.com

\section{Citation:}

Carvalho J.F., Cordeiro L.R., Silva F.F., Mota L., Rodrigues C., Andrade C.F., Caldas C. Profile of several autoantibodies, complement and vitamin D levels in Brazilian patients with Chikungunya infection // Russian Journal of Infection and Immunity = Infektsiya i immunitet, 2021, vol. 11, no. 5, pp. 979-983. doi: 10.15789/2220-7619-POS-1614 


\title{
ПРОФИЛЬ УРОВНЕЙ НЕКОТОРЫХ АУТОАНТИТЕЛ, КОМПЛЕМЕНТА И ВИТАМИНА Ф У БОЛЬНЫХ С ИНФЕКЦИЕЙ ЧИКУНГУНЬЯ В БРАЗИЛИИ
}

\author{
Карвальо Дж.Ф. ${ }^{1}$, Кордейро Л.Р. ${ }^{1}$, Силва Ф.Ф. ${ }^{2}$, Мота Л. ${ }^{3}$, Родригес К. ${ }^{4}$, Андраде К.Ф. ${ }^{5,6}$, Кальдас С. ${ }^{7}$ \\ ${ }^{I}$ Федеральный университет Байи, г. Салвадор, Бразилия \\ ${ }^{2}$ Университет Сан-Паулу, г. Сан-Паулу, Бразилия \\ ${ }^{3}$ Университет г. Бразилиа, г. Бразилиа, Бразилия \\ ${ }^{4}$ Университет Форталеза, г. Форталеза, Бразилия \\ ${ }^{5}$ Национальная школа здравоохранения Сержиу Ароука, г. Рио-де-Жанейро, Бразилия \\ ${ }^{6}$ Университет Васорас, г. Рио-де-Жанейро, Бразилия \\ ${ }^{7}$ Федеральный университет штата Пара, г. Белен, Бразилия
}

Резюме. Введение. Инфекция вирусом чикунгунья (CKV) может приводить к хроническому артриту у $40 \%$ пациентов. Существуют ранее полученные данные об обнаружении аутоантител при CKV-инфекции. Цель оценка наличия аутоантител у пациентов с CKV. Meтоды. У всех участников исследования были отмечены клинические проявления CKV-инфекции, получены положительные результаты, по крайней мере, серологического анализа или OT-ПЦР на CKV и выявлены следующие аутоантитела: антинуклеарные (ANA), антиdsDNA, анти-Sm, анти-Ro/SS-A, анти-La/SS-B, анти-U1RNP, антикардиолипин IgG и IgM, антициклический цитруллинированный пептид (анти-CCP), ревматоидный фактор (RF), антитела к антирибосомному белку P, волчаночный антикоагулянт, анти-Jo-1 и анти-Scl-70. Также исследовались уровень компонентов комплемента $\mathrm{C} 3$ и $\mathrm{C} 4$, общая активность комплемента (CH100), сывороточные уровни иммуноглобулинов, С-реактивный белок, скорость оседания эритроцитов, альфа-кислотный гликопротеин, антитиреоглобулин, антитиреопероксидаза, TRAb, 25-гидроксивитамин D (25OHD), антитела IgG и IgM к вирусам денге и Зика.

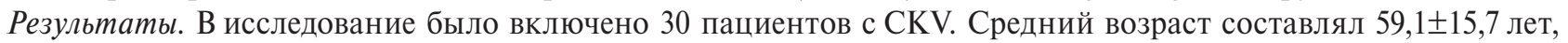
85\% составляли женщины, 77\% - представители европеоидной расы. Давность заболевания составила $4,9 \pm 4,0$ мес. Олигоартрит отмечен у 93\% обследованных. Средние уровни С-реактивного белка составляли $10,1 \pm 6,8$ нг/дл, СОЭ - 34,2 19,9 мм/ч и альфа-1-кислотный гликопротеин $-115,5 \pm 52,6$ мг/дл. Внутримышечная инъекция депо бетаметазона в разовой дозе применялась в $54 \%$ случаев, преднизон - в $15 \%$ и метотрексат - в 23\%. Важно отметить, что 1 проба из 30 (3,3\%) была положительной на ANA, 4 из 30 (13,3\%) - на RF, и ни одна не была положительной на анти-ССР или любые другие аутоантитела. Уровни комплемента и иммуноглобулина были в пределах нормы. Низкие уровни $25 \mathrm{OHD}$ наблюдались в $88 \%$ случаев. Заключение. Хотя мы наблюдали высокий процент суставных проявлений у пациентов с CKV, настоящее исследование обнаружило низкую частоту аутоантител у пациентов с CKV.

Ключевые слова: Чикунгунья, аутоантитела, аутоиммунитет, арбовироз, ревматоидный артрит.

\section{Introduction}

The Chikungunya virus (CKV), a member of the Togaviridae family, Alphavirus genus, was first isolated from humans in 1952, in the coastal area of Muawiya, Makondo and Rondo, currently known as Tanzania. Brazil had a large outbreak of CKV between September 2014 and 2017. Until the $37^{\text {th }}$ epidemiological week, 236,287 probable cases of CKV were evaluated and 116,523 were serologically confirmed [4]. In the literature, from $14.4 \%$ to $87.2 \%$ of these cases may evolve to chronic joint involvement [9].

Previous data have found some percentage of autoantibodies in CKV. In this research line, antinuclear antibodies (ANA), rheumatoid factor, and anti-cyclic citrullinated peptide (anti-CCP) were previously studied in CKV scenario [2].

Our group has recently described the characteristics of $63 \mathrm{CKV}$ patients from Brazilian Amazon, which the main arthritis pattern identified was oligoarticular, with a predominance of ankles and knees, and also with a chronicity rate of $48 \%$, however no autoantibody was studied. Until now, we do not have any knowledge of studies in which several autoantibodies profile in CKV were systematically analised [11].
Therefore, this study aims to systematically investigate the profile of several autoantibodies in patients with confirmed CKV infection.

\section{Methods}

All study participants had clinical manifestations (fever, rash and arthritis) and positivity for at least serology (IgG and/or IgM) or RT-PCR fulfilling the diagnosis of CKV infection [14]. Anti-Chikungunya IgG and IgM antibodies were detected using a singleserum monoclonal antibody-capture enzyme-linked immunosorbent assay (ELISA) technique. This research is characterized as a descriptive cross-sectional study that was conducted at a private clinic in Salvador, Bahia State, Brazil. All patients had negative IgM serology for dengue since this arbovirus is an important differential diagnosis.

All patients agreed to participate and were requested to sign an informed consent of participation.

Laboratory evaluation. All tests were collected before treatment. Antinuclear antibodies were detected by indirect immunofluorescence (IIF) using HEp-2 cells as substrate. Anti-dsDNA antibodies were also detected by IIF using Crithidia luciliae. The presence of IgG and IgM anticardiolipin antibodies (aCL) was 
analyzed by padronized ELISA, and positive values were considered above 10GPL and 10MPL, respectively. The following antibodies anti-Ro/SS-A, anti-La/ SS-B, anti-U1RNP and anti-Sm were performed using ELISA and immunodiffusion; anti-CCP by chemiluminescence with microparticles; RF by nephelometry and normal values were considered below $14 \mathrm{IU} / \mathrm{mL}$; antiribosomal $\mathrm{P}$ by ELISA; lupus anticoagulant by functional assays (activated partial thromboplastin time and diluted Russell viper venom time); anti-Jo-1 and anti-Scl-70 by ELISA and double immunodiffusion; and antithyroglobulin, antithyroperoxidase and TRAb by competitive immunoassay and electrochemiluminescence. Total hemolytic complement activity (CH100) was measured by immunohemolysis assay (normal range 150-350 units/ml). Serum levels of C3 and $\mathrm{C} 4$ complement components were determined by immunodiffusion test (Dade Behring Marburg, Marburg, Germany). C3 normal range is $84-167 \mathrm{mg} \%$, and C4 normal range is $16-31 \mathrm{mg} \%$. The erythrocyte sedimentation rate was measured by Westergren method and C-reactive protein by nephelometry. $25 \mathrm{OHD}$ was measured by chemiluminescence. Low levels of this vitamin were considered when lower than $20 \mathrm{ng} / \mathrm{mL}$. Serum levels of $\mathrm{IgG}, \mathrm{IgA}$ and $\mathrm{Ig}$ M immunoglobulins were measured by nephelometry and $\operatorname{IgE}$ by immunofluorimetry.

Chikungunya detection Anti-Chikungunya Virus ELISA (IgG and IgM) (Euroimmun, Germany) was used to detect antibodies to CKV.

Viral RNA was extracted using a QIAmp Viral Mini Kit (Qiagen, Inc., USA), following the manufacturer's instructions and amplified by reverse transcription polymerase chain reaction (PCR) using primers for CHIKV accordingto previously described protocols. In summary, the RT-PCR assay for detection of CHIK was realized using the GoTaq ${ }^{\circledR}$ Probe1-Step RT-qPCR System (Promega) following recommendations of the manufacturer. The reaction was carried out using an ABI 7500 Real Time PCR system. The processing of all samples included negative and positive controls as well as internal controls (Ribonuclease P, RNAse P) to ensure reliability of the reaction.

Statistical analysis. Results were expressed as meant standard deviations (SD), median (range) or frequency as percentage. Windows Excel was the used program.

\section{Results}

The main data is summarized in the Table. Mean age of all $30 \mathrm{CKV}$ patients was $59.1 \pm 15.7$ years, $85 \%$ were female and $77 \%$ were caucasian while $33 \%$ were black or mulatto. The disease duration was $4.9 \pm 4.0$ months. Comorbidities were reported in $50 \%$ of patients and were: osteoarthritis in 50\%, systemic hypertension in $25 \%$, obesity in $25 \%$ and diabetes in $13 \%$. Nine out 26 (35\%) had previously used non-steroidal anti-inflammatory drugs. Oligoarthritis was observed in most of the cases (93\%) and polyarthritis in $7 \%$. Ankles followed by the knees were the most common involved joints.
Serology (IgG and or IgM) for CKV was positive in $25(83.32 \%)$ and one patient had positive RT-PCR for $\mathrm{CKV}$ at inclusion. Median levels of antibodies to $\mathrm{CKV}$ were IgG CKV 15.0 (0-198) and IgM CKV 5.42 (0.293-34.8). All patients were negative for IgM dengue antibodies, but $19 \%$ had positive IgG. IgG Zika positivity was detected in $1 / 30$ patient. Ultrasensitive C-reactive protein levels were $10.1 \pm 6.8 \mathrm{ng} / \mathrm{dL}$ and erythrocyte sedimentation rate $34.2 \pm 29.9 \mathrm{~mm} / 1^{\text {st }}$ hour.

Intramuscular betamethasone depot injection in a single dose was administered in $54 \%$, oral prednisone initiated in $15 \%$ and methotrexate in $23 \%$ of the cases. Importantly, 1/30 (3.3\%) was positive for ANA, 4/30 (13.3\%) for RF and none was positive for antiCCP or any other autoantibodies (anti-dsDNA, antiRo/SS-A, anti-La/SS-B, anti-RNP, anti-Sm, antiribosomal $\mathrm{P}$, anti-CCP, lupus anticoagulant, IgG and IgM anticardiolipin, anti-Jo-1, anti-Scl-70 and antithyroid antibodies). Titles of RF were very low and were: $17.61,16.88,16.30$ and $15.7 \mathrm{IU} / \mathrm{mL}$. Complement and immunoglobulin levels were all within the normal range. Low levels of $25 \mathrm{OHD}$ was observed in $88 \%$ of the cases.

\section{Discussion}

To our knowledge, this is the first study to systematically evaluate the prevalence of several autoantibodies in patients with CKV infection using highly specific methods. The pathogenesis of arthropathy following

Table. Demographic, clinical and treatment features of the 30 patients with Chikungunya arthritis

\begin{tabular}{|l|c|}
\hline \multicolumn{1}{|c|}{ Features } & $\begin{array}{c}\text { CKV patients } \\
\text { (n = 30) }\end{array}$ \\
\hline Age, years & $59.1 \pm 15.7$ \\
\hline Caucasian race & $77 \%$ \\
\hline Female gender & $88 \%$ \\
\hline Disease duration, months & $4.9 \pm 4.0$ \\
\hline Diabetes mellitus & $13 \%$ \\
\hline Systemic arterial hypertension & $25 \%$ \\
\hline Obesity & $25 \%$ \\
\hline Osteoarthritis & $50 \%$ \\
\hline Oligoarthritis & $93 \%$ \\
\hline Polyarthritis & $7 \%$ \\
\hline C-Reactive protein, mg/dL & $10.1 \pm 6.8$ \\
\hline ESR ${ }^{\star}$, mm/1st hour & $34.2 \pm 29.9$ \\
\hline IgG CKV ${ }^{*}$ median levels (range) & $15.0(0-198)$ \\
\hline IgM CKV* median levels (range) & $5.42(0.293-34.8)$ \\
\hline Oral prednisone & $15 \%$ \\
\hline Intramuscular betamethasone use & $54 \%$ \\
Methotrexate use $^{*}$ & $23 \%$ \\
\hline 25OHD* low levels & $88 \%$ \\
\hline ANA* & $3.3 \%$ \\
\hline Rheumatoid factor $^{*}$ & $13 . \%$ \\
\hline
\end{tabular}

Note. Values are expressed in mean \pm SD or percentage (\%). ANA: antinuclear antibodies; CKV: Chikungunya infection; ESR: erythrocyte sedimentation rate; 250HD: 25-hydroxyvitamin D. 
infection with CKV is not completely clear; however, based on studies conducted with other arthritogenic viruses, arthritis possibly occurs due to the virus' ability to replicate and mediate the production of tissue damage in joints, which in turn depends on the host immune response [12].

In previous studies, some patients met the international classification criteria for rheumatoid arthritis and spondyloarthritis in the chronic phase of the disease [7]. In addition, there are reports of exacerbation of cutaneous psoriasis and of onset of psoriasis after CKV [6]. In a study that compared untreated rheumatoid arthritis and CKV patients using cytometric analysis of blood mononuclear cells, the authors found higher percentages of activated and effector CD4p and CD8p T lymphocytes in CKV and also in rheumatoid arthritis than in healthy controls. In conclusion, CKV and RA patients have similarities regarding clinical features and lymphocyte activation [10].

Furthermore, another article which described 21 new cases of RA following CKV infection and observed autoantibodies. Interesting that after 21 months, $81 \%$ had erosions and importantly rheumatoid factor were positive in $57 \%$ and anti-CCP in $28 \%$ of these cases [2]. Autoimmunity in CKV was reviewed by Tanay in 2017 [13].

A large cross-sectional study was conducted in Colombia with 907 patients with clinically confirmed $(n=424)$ or laboratory-confirmed $(n=483)$ chikungunya virus infection. Of these patients, 65 were randomly selected for eligibility screening, of whom 38 were eligible for study participation in the chronic arthritis group. Synovial fluid analysis revealed no detectable chikungunya virus. Thus, we can assume that the virus can cause arthritis by an autoantibody induction mechanism in infected patients [3].

Recently, Cavalcanti et al. have described increased serum levels of galactin-9 in patients with Chikungunya fever [5]. Galectins are a family of animal lectins with an affinity for beta-galactosides, that have multiple functions including working as receptors in innate immunity and as a control for inflammatory responses in both innate and adaptive immunity. Galactins regulate functions of immune cells, such as lymphocytes and macrophages, which have a main role in the chikungunya inflammatory process. These authors suggested galactin-9 may play a hole in the immunopathogenesis of the inflammatory process in chikungunya fever, as morning stiffness may reflect the systemic inflammatory process.

Regarding the antibodies profile in CKV patients, previous studies have evaluated a few numbers of autoantibodies, almost exclusively RF, ANA and antiCCP. In this line, most of these studies does not describe the laboratory methodology used to detect the autoantibodies. In just a few the methodology was stated using more modern techniques such ELISA for anti-CCP and nephelometry for RF [2, 8]. No autoantibodies were found in the Blettery study, including 147 patients [4]. In Bouquillard et al. study, with
21 patients, the authors found a high positivity for RF of $57.1 \%$, anti-CCP $28.6 \%$ and $9.5 \%$ for ANA [2].

Antinuclear antibodies were evaluated in 2 studies involving $\mathrm{CKV}$ patients being found a positivity from 0 to $30 \%$, on the other hand, the frequency of rheumatoid factor and anti-CCP ranged from 0 to $57.1 \%$ and 0 to $56.5 \%$ in 8 studies, respectively. Therefore, the real frequency of positivity for autoantibodies was currently unknown. Giving the past studies on the theme, our study differential includes systematic evaluation of several autoantibodies' profile in CKV patients with arthropathy referred to rheumatology service, using highly specific methods for antibodies detection.

We have found a prevalence of $11.5 \%$ of rheumatoid factor in our CKV population what is higher than the described in the literature (about 1-2\%) on health people. In clinical practice, this fact can make the differentiation between CKV arthropathy and rheumatoid arthritis triggered by virus infection even harder. On the other hand, the presence of anti-CCP should strengthen the suspicion of RA, as well as the presence of bone erosions, as shown in other studies [9]. The main strength of this study relies on its originality about the wide variety of autoantibodies studied in these patients. The use of standardized and recommended techniques in the guidelines for the measurement of autoantibodies is another original point. Moreover in the presence of varied rheumatic manifestations that may happen in the chronic phase of CKV, the positivity of the specific autoantibodies evaluated in this study could help to investigate differential diagnosis, since low positivity found in our population, is an auxiliary element in decision making when added to clinical evaluation. The limitations of this study also need to be addressed. First, the number of patients included was relatively small; second, we did not standardize a specific time after the onset of CKV infection to include patients. Maybe if we performed the autoantibody evaluation in a long-term CKV infection, the positivity for autoantibodies could increase.

\section{Conclusion}

This study suggests that the presence of autoantibodies in patients with Chikungunya in about 4 months of infection onset is low. Mainly represented by ANA and RF positivity when standard techniques with good specificity are performed. However, future studies including many participants are needed to confirm the present data.

\section{Highlights}

- Chikungunya virus infection may induce autoimmunity;

- We observed a low frequency of autoantibodies in this study with $13.3 \%$ of rheumatoid factor and $3.3 \%$ of antinuclear antibodies.

No patient had positivity for anti-CCP or evolved with a fullblown autoimmune rheumatic disease. 


\section{References}

1. Blettery M., Brunier L., Polomat K., Moinet F., Deligny C., Arfi S., Jean-Baptiste G., De Bandt M. Brief report: management of chronic post-Chikungunya rheumatic disease: the martinican experience. Arthritis Rheumatol., 2016, vol. 68, no. 11, pp. 28172824. doi: 10.1002/art.39775

2. Bouquillard E., Combe B. A report of 21 cases of rheumatoid arthritis following Chikungunya fever. A mean follow-up of two years. Joint Bone Spine, 2009, vol. 76, no. 6, pp. 654-657. doi: 10.1016/j.jbspin.2009.08.005

3. Chang A.Y., Martins K.A.O., Encinales L., Reid S.P., Acuña M., Encinales C., Matranga C.B., Pacheco N., Cure C., Shukla B., Ruiz Arteta T., Amdur R., Cazares L.H., Gregory M., Ward M.D., Porras A., Rico Mendoza A., Dong L., Kenny T., Brueggemann E., Downey L.G., Kamalapathy P., Lichtenberger P., Falls O., Simon G.L., Bethony J.M., Firestein G.S. Chikungunya arthritis mechanisms in the Americas: a cross-sectional analysis of Chikungunya arthritis patients twenty-two months after infection demonstrating no detectable viral persistence in synovial fluid. Arthritis Rheumatol., 2018, vol. 70, no. 4, pp. 585-593. doi: 10.1002/art.40383

4. Faria N.R., Lourenco J., Cerqueira E.M., Lima M.M., Pybus O., Alcantara L.C.J. Epidemiology of Chikungunya virus in Bahia, Brazil, 2014-2015. PLoS Curr., 2016, vol. 8: ecurrents.outbreaks.c97507e3e48efb946401755d468c28b2. doi: 10.1371/currents.outbreaks.c97507e3e48efb946401755d468c28b2

5. Gualberto Cavalcanti N., Melo Vilar K., Branco Pinto Duarte A.L., Barreto de Melo Rêgo M.J., Pereira M.C., da Rocha Pitta I., Diniz Lopes Marques C., Galdino da Rocha Pitta M. Increased serum levels of galectin-9 in patients with chikungunya fever. Virus Res., 2020, vol. 286: 198062. doi: 10.1016/j.virusres.2020.198062

6. Inamadar A.C., Palit A., Sampagavi V.V., Raghunath S., Deshmukh N.S. Cutaneous manifestations of chikungunya fever: observations made during a recent outbreak in south India. Int. J. Dermatol., 2008, vol. 47, no. 2, pp. 154-159. doi: 10.1111/j.13654632.2008.03478.x

7. Javelle E., Ribera A., Degasne I., Gaüzère B.A., Marimoutou C., Simon F. Specific management of post-chikungunya rheumatic disorders: a retrospective study of 159 cases in Reunion Island from 2006-2012. PLoS Negl. Trop. Dis., 2015, vol. 9, no. 3: e0003603. doi: 10.1371/journal.pntd.0003603

8. Manimunda S.P., Vijayachari P., Uppoor R., Sugunan A.P., Singh S.S., Rai S.K., Sudeep A.B., Muruganandam N., Chaitanya I.K., Guruprasad D.R. Clinical progression of chikungunya fever during acute and chronic arthritic stages and the changes in joint morphology as revealed by imaging. Trans. R. Soc. Trop. Med. Hyg., 2010, vol. 104, no. 6, pp. 392-399.

9. Marques C.D.L., Duarte A.L.B.P., Ranzolin A., Dantas A.T., Cavalcanti N.G., Gonçalves R.S.G., Rocha Junior L.F.D., Valadares L.D.A., Melo A.K.G., Freire E.A.M., Teixeira R., Bezerra Neto F.A., Medeiros M.M.D.C., Carvalho J.F., Santos M.S.F., Océa R.A.L.C., Levy R.A., Andrade C.A.F., Pinheiro G.D.R.C., Abreu M.M., Verztman J.F., Merenlender S., Ribeiro S.L.E., Costa I.P.D., Pileggi G., Trevisani V.F.M., Lopes M.I.B., Brito C., Figueiredo E., Queiroga F., Feitosa T., Tenório A.D.S., Siqueira G.R., Paiva R., Vasconcelos J.T.S., Christopoulos G. Recommendations of the Brazilian Society of Rheumatology for diagnosis and treatment of Chikungunya fever. Part 1 - Diagnosis and special situations. Rev. Bras. Reumatol., 2017, vol. 57, pp. 421-437. doi: 10.1016/j.rbre.2017.05.006

10. Miner J.J., Yeang H.X.A., Fox J.M., Taffner S., Malkova O.N., Oh S.T., Kim A.H.J., Diamond M.S., Lenschow D.J., Yokoyama W.M. Brief report: chikungunya viral arthritis in the United States: a mimic of seronegative rheumatoid arthritis. Arthritis Rheumatol., 2015, vol. 67, no. 5, pp. 1214-1220. doi: 10.1002/art.39027

11. Pereira A.B.C., Albuquerque L.C.F., Souza R.C.M., Carvalho J.F., Caldas C.A.M. Musculoskeletal manifestations observed in patients diagnosed with Chikungunya virus in 2 municipalities of the Brazilian Amazon Region. J. Clin. Rheumatol., 2020, vol. 26, no. 7S, suppl. 2, pp. S195-S198. doi: 10.1097/RHU.0000000000001366

12. Rulli N.E., Melton J., Wilmes A., Ewart G., Mahalingam S. The molecular and cellular aspects of arthritis due to alphavirus infections: lesson learned from Ross River virus. Ann. NY Acad. Sci., 2007, vol. 1102, pp. 96-108. doi: 10.1196/annals.1408.007

13. Tanay A. Chikungunya virus and autoimmunity. Curr. Opin. Rheumatol., 2017, vol. 29, no. 4, pp. 389-393. doi: 10.1097/ BOR.0000000000000396

14. Wahid B., Ali A., Rafique S., Idrees M. Global expansion of chikungunya virus: mapping the 64-year history. Int. J. Infect. Dis., 2017, vol. 58, pp. 69-76. doi: 10.1016/j.ijid.2017.03.006

\author{
Авторы: \\ Карвальо Дж.Ф., д.н., кафедра здравоохранения Федерального \\ университа Баии, г. Салвадор, Бразилия; \\ Кордейро Л.Р., аспирант Школы медицины и здравоохранения \\ Баии Федерального университета Баии, г. Салвадор, Бразилия; \\ Силва Ф.Ф., докторант академической клиники факультета \\ медицины Университета Сан-Паулу, г. Сан-Паулу, Бразилия; \\ Мота Л., д.н., ассистент службы ревматологии университетской \\ больницы г. Бразилиа Университета г. Бразилиа, г. Бразилиа, \\ Бразилия; \\ Родригес К., д.н., доцент, Университет Форталеза, \\ г. Форталеза, Бразилия; \\ Андраде С.Ф., д.н., доцент кафедры эпидемиологии \\ и количественных методов в здравоохранении Национальной \\ школа здравоохранения Сержиу Ароука, г. Рио-де-Жанейро, \\ Бразилия; факультет медицины, Университет Васорас, \\ г. Рио-де-Жанейро, Бразилия; \\ Кальдас С., д.н., доцент факультета медицины Центра \\ тропической медицины Федерального университета штата \\ Пара, г. Белен, Бразилия. \\ Поступила в редакцию 15.10.2020 \\ Отправлена на доработку 15.03.2021 \\ Принята к печати 15.03.2021
}

\section{Authors:}

Carvalho J.F., MD, PhD, Institute for Health Sciences, Federal University of Bahia, Salvador, Brazil;

Cordeiro L.R., Graduate Student, Bahian School of Medicine and Public Health, Federal University of Bahia, Salvador, Brazil; Silva F.F., MD, Doctoral Student, Clinics Hospital of Faculty of Medicine, University of São Paulo, São Paulo, Brazil;

Mota L., MD, PhD, Assistant Professor, Rheumatology Service, University Hospital of Brasilia, University of Brasilia, Brasilia, Brazil; Rodrigues C., MD, PhD, Assistant Professor, University of Fortaleza, Fortaleza, Brazil;

Andrade C.F., MD, DSc, Assistant Professor, Department of Epidemiology and Quantitative Methods in Health, National School of Public Health Sérgio Arouca, Rio de Janeiro, Brazil; Faculty of Medicine, Vassouras University, Rio de Janeiro, Brazil;

Caldas C., MD, PhD, Assistant Professor, Faculty of Medicine, Tropical Medicine Center, Federal University of Pará, Belém, Brazil. 